\title{
Terapi Asiklovir pada Anak dengan Varisela Tanpa Penyulit
}

\author{
Theresia, Sri Rezeki S. Hadinegoro \\ Departemen Ilmu Kesehatan Anak, RS Dr Cipto Mangunkusumo, Fakultas Kedokteran Universitas \\ Indonesia, Jakarta
}

\begin{abstract}
Varisela atau chickenpox atau yang dikenal dengan cacar air adalah infeksi primer virus zoster varicella (VZV) yang umumnya menyerang anak dan merupakan penyakit yang sangat menular. Varisela pada anak tanpa penyulit adalah ringan dan dapat sembuh sendiri. Pengobatan varisela bersifat simtomatik, namun dalam praktek sehari-hari, masih banyak dokter yang memberikan asiklovir oral. Asiklovir sebagai terapi varisela sudah lama digunakan termasuk pada anak sehat tanpa penyulit walaupun sampai saat ini masih kontroversial. Berdasarkan hasil penelusuran didapatkan 8 artikel yang relevan yang dapat disimpulkan bahwa bila asiklovir diberikan dalam 24 jam pertama timbulnya ruam, secara signifikan dapat mengurangi hari lamanya demam, memperpendek lama sakit, mengurangi jumlah lesi, tapi tidak mengurangi komplikasi varisela (level of evidence 1a). Namun asiklovir tidak dianjurkan diberikan secara rutin pada anak varisela tanpa penyulit, karena ada pendapat bahwa kemungkinan terjadinya resistensi terhadap asiklovir dan menganggu imunitas serta masalah biaya yang mahal. (Sari Pediatri 2010;11(6):440-47).
\end{abstract}

Kata kunci: varisela, anak sehat, asiklovir

$\mathrm{V}$ arisela atau chickenpox atau yang dikenal dengan cacar air adalah infeksi primer virus varicella-zoster (VZV) yang umumnya menyerang anak dan merupakan penyakit yang sangat menular. Sedangkan herpes zoster atau shingles adalah reaktivasi infeksi endogen pada periode laten virus varicella-zoster yang pada umumnya menyerang orang dewasa atau anak dengan defisiensi imun. Meskipun gejala klinis varisela tidak berat

Alamat korespondensi:

Prof. DR. Dr. Sri Rezeki S. Hadinegoro Sp.A(K). Divisi Infeksi dan Pediatri Tropis Departemen Ilmu Kesehatan Anak FKUI-RSCM Jl. Salemba no. 6, Jakarta 10430. Telepon: 021-3914126. Fax.021-390 7743. namun pada remaja, orang dewasa dan anak dengan status imunitas menurun dapat meningkatkan angka kesakitan dan kematian., ${ }^{1,2}$

Varisela dapat mengenai semua kelompok umur termasuk neonatus, tetapi hampir sembilan puluh persen kasus mengenai anak dibawah umur 10 tahun dan terbanyak pada umur 5-9 tahun. ${ }^{2}$ Di Amerika Serikat, sebelum diperkenalkan vaksin varisela terjadi epidemi varisela tahunan setiap musim dingin dan musim semi, tercatat sekitar 4 juta kasus. Pada tahun 2000 , angka kejadian varisela menurun $71 \%-84 \%$ sejak diperkenalkannya vaksin varisela. Angka kesakitan dan kematian menurun terutama pada kelompok umur 1-4 tahun. ${ }^{1}$ Angka kejadian varisela di Indonesia belum pernah diteliti sedangkan berdasarkan data dari polikli- 
nik umum Ilmu Kesehatan Anak Rumah Sakit Cipto Mangunkusumo (IKA-RSCM) dalam lima tahun terakhir tercatat 77 kasus varisela tanpa penyulit.

Penularan varisela terutama melalui kontak langsung dari lesi di kulit atau melalui droplet sekret saluran nafas yang dapat terjadi 24 sampai 48 jam sebelum timbulnya ruam sampai menjadi keropeng, pada umumnya 5-7 hari setelah timbulnya ruam. Pada anak sehat, manifestasi klinis varisela umumnya ringan, dapat sembuh sendiri, dan jarang menimbulkan penyulit yang serius. ${ }^{3}$

Pengobatan varisela bersifat simtomatik seperti pemberian calamine lotion lokal pada lesi kulit, untuk mengurangi rasa gatal dapat diberikan kompres dingin, mandi secara teratur atau pemberian antihistamin. Asiklovir sebagai terapi varisela sudah lama digunakan termasuk pada anak sehat tanpa penyulit walaupun sampai saat ini masih kontroversial apakah perlu diberikan secara rutin pada anak sehat tanpa penyulit. Pada anak sehat atau tanpa penyulit yang menderita varisela, asiklovir terbukti dapat mengurangi lama terjadinya demam dan mengurangi banyaknya lesi yang timbul. Namun masih kurangnya bukti tentang asiklovir dapat mencegah terjadinya komplikasi dan adanya kemungkinan terjadinya resistensi terhadap asiklovir bila dipergunakan secara luas. ${ }^{4}$ Masalah biaya pun merupakan salah satu pertimbangan, karena itu timbul pertanyaan apakah diperlukan pemberian asiklovir secara rutin pada penderita varisela tanpa penyulit?

\section{Kasus}

Seorang anak perempuan berusia 4 tahun 8 bulan datang ke Poliklinik Umum Departemen IKA RSCM pada tanggal 23 Desember 2009 dengan keluhan utama timbul lentingan-lentingan berisi cairan di kulit dada sejak satu hari yang lalu. Satu hari sebelum datang ke RSCM, pasien demam tidak tinggi, naik turun disertai timbulnya beberapa lentingan berisi cairan di dada pasien. Saat itu pasien tidak menderita batuk, pilek, maupun diare sehingga ibu pasien hanya memberikan parasetamol untuk menurunkan demam. Keesokan harinya lentingan bertambah banyak dan menyebar ke daerah wajah dan punggung, disertai demam dan berkurangnya nafsu makan sehingga ibu membawa pasien berobat ke RSCM.

Riwayat kehamilan dan kelahiran, pasien adalah anak tunggal, lahir cukup bulan spontan dengan berat lahir 2700 gram dan panjang lahir $48 \mathrm{~cm}$. Pasien pernah dirawat di RS Persahabatan pada usia tujuh bulan karena kejang demam. Pada pasien terdapat riwayat kontak dengan tetangga rumah yang menderita varisela dua minggu sebelumnya. Riwayat imunisasi dasar lengkap namun belum pernah mendapatkan vaksin varisela. Tidak terdapat riwayat alergi obat maupun alergi makanan. Riwayat tumbuh kembang dalam batas normal. Riwayat nutrisi terkesan kualitas dan kuantitas kurang.

Pada pemeriksaan fisis, kesadaran umum pasien kompos mentis, tidak sesak maupun sianosis. Frekuensi nadi 104 kali per menit, teratur, isi cukup dengan frekuensi napas 24 kali per menit, teratur, kedalaman cukup, suhu aksila $38,7^{\circ} \mathrm{C}$. Berat badan pasien $15 \mathrm{~kg}$ (P10 kurva CDC 2000), tinggi badan $104 \mathrm{~cm}$ (P10 kurva CDC 2000) dengan kesan klinis gizi kurang. Pada kulit daerah wajah, dada bagian atas dan punggung tampak beberapa makula, papul, jumlah kurang dari sepuluh vesikel, dengan dinding yang tipis dan tampak seperti tetesan air dengan dasar kemerahan. Tidak terdapat vesikel di tempat lainnya seperti mukosa mulut atau di faring. Pemeriksaan jantung, paru, abdomen, dan ekstremitas dalam batas normal.

Berdasarkan riwayat kontak dan pemeriksaan fisis maka diagnosis ditegakkan sebagai varisela dan gizi kurang. Pasien diberi parasetamol dan asiklovir 4x400 mg per oral untuk lima hari dan dianjurkan untuk kembali ke RSCM setelah obat habis, tetapi pasien tidak kembali karena menurut ibu pasien melalui telpon setelah dua hari minum obat demam sudah turun dan lentingan yang ada mengering serta tidak bertambah banyak.

\section{Masalah klinis}

Varisela pada anak tanpa penyulit pada umumnya ringan dan sembuh sendiri dengan pengobatan simtomatik. Asiklovir merupakan obat pilihan utama pada varisela yang pemberiannya pada kasus varisela tanpa penyulit masih merupakan kontroversi. Berdasarkan hal tersebut, diajukan pertanyaan klinis sebagai berikut: Apakah asiklovir perlu diberikan pada varisela tanpa penyulit pada anak sehat?

\section{Strategi penelusuran}

Untuk menjawab masalah klinis tersebut dilakukan 
penelusuran pustaka secara online menggunakan instrumen pencari PubMed, Cochrane Library, OvidSP, dan American Academy of Pediatrics (AAP). Kata kunci yang dipergunakan adalalah "varicella", "chickenpox", "healthy children", dan "acyclovir" dengan menggunakan batasan publikasi bahasa Inggris, publikasi 20 tahun terakhir, kata kunci terdapat pada judul atau abstrak. Pada awalnya didapatkan 35 artikel yang memenuhi kriteria inklusi. Penelusuran lebih lanjut dilakukan secara manual pada daftar pustaka yang relevan dan didapatkan delapan artikel yang relevan dengan masalah, yaitu dua artikel telaah sistematik, empat artikel uji klinis acak ganda, satu artikel kohort, dan satu pendapat ahli. Level of evidence ditentukan atas dasar klasifikasi yang dikeluarkan oleh Oxford Centre for Evidence-Based Medicine. ${ }^{5}$

\section{Hasil penelusuran}

Dua puluh delapan tahun yang lalu, asiklovir telah digunakan untuk pengobatan varisela pada anak imunokompromais dan varisela pada orang dewasa yang sehat, namun belum ada penelitian pada anak sehat. Balfour $\mathrm{HH} \mathrm{dkk}^{6}$ pada tahun 1990 pertama kali mempublikasikan bahwa terapi asiklovir oral bermanfaat dan dapat ditoleransi dengan baik untuk pengobatan varisela pada anak sehat. Balfour $\mathrm{HH} \mathrm{dkk}$ membandingkan plasebo dan asiklovir dengan dosis 10,15 dan $20 \mathrm{mg} / \mathrm{kg}$ dan menemukan bahwa kelompok yang diberi asiklovir lebih cepat hilang demam $(\mathrm{p}=0,001)$ dan penyembuhan lesi kulit yang lebih cepat $(\mathrm{p}=0,002)$, dan lesi kulit yang timbul lebih sedikit $(\mathrm{p}=0,02)$ dibandingkan kelompok plasebo (level of evidence: 1b). Namun asiklovir tidak mengurangi komplikasi varisela yaitu $13,5 \%$ pada kelompok plasebo dan $10 \%$ pada kelompok asiklovir. Semua komplikasi bersifat ringan dan sembuh dalam dua minggu atau kurang. Komplikasi tersebut meliputi otitis media, infeksi bakteri pada kulit, faringitis streptokokus, pneumonia, dan meningoensefalitis. Titer antibodi terhadap VZV pada kelompok asiklovir didapatkan lebih rendah dibandingkan kelompok plasebo pada 28 hari pertama, namun setelah 1 tahun mencapai titer antibodi yang sama.

Uji klinis acak ganda oleh Balfour $\mathrm{HH} \mathrm{dkk}^{6}$ menunjukkan asiklovir dengan dosis $20 \mathrm{mg} / \mathrm{kg}$ memberikan hasil yang lebih baik. Berdasarkan hasil observasi tersebut, pada tahun 1991 Dunkle LM dkk melakukan uji klinis acak ganda berskala besar pada
815 anak umur 2-12 tahun. Hasil penelitiannya adalah asiklovir oral yang diberikan dalam 24 jam setelah ruam timbul dengan dosis $20 \mathrm{mg} / \mathrm{kg} 4$ kali sehari selama lima hari dapat mengurangi lama sakit dan jumlah lesi yang timbul $(\mathrm{p}<0,001)$ (level of evidence: $1 \mathrm{~b})$. Tidak terdapat perbedaan yang signifikan secara statistik dalam hal komplikasi varisela maupun titer antibodi terhadap VZV pada kelompok asiklovir dan plasebo. Dua penelitian di atas juga menyatakan bahwa anak yang menderita varisela yang ditularkan dari tempat tinggal yang sama umumnya memiliki manifestasi klinis yang lebih berat, seperti jumlah lesi kulit yang lebih banyak dan lesi yang lebih lama menghilang.

Uji klinis oleh Balfour $\mathrm{HH} \mathrm{dkk}^{6}$ memperkirakan bahwa manifestasi klinis varisela pada remaja lebih berat dibandingkan anak yang lebih muda sehingga pada tahun 1992 Balfour $\mathrm{HH}$ dkk$^{8}$ melakukan uji klinis acak ganda pada 62 remaja umur 13-18 tahun untuk mengkonfirmasi hipotesis ini. Pada penelitian ini didapatkan kelompok remaja memiliki gejala yang lebih berat dibandingkan pada anak, dan sebaiknya diberikan asiklovir oral dengan dosis $800 \mathrm{mg} / \mathrm{kali} 4$ kali selama lima hari yang terbukti aman dan efektif. Jumlah lesi baru lebih sedikit dibandingkan kelompok placebo $(\mathrm{p}<0,001)$.

Pada tahun 1992 Food and Drug Administration (FDA) menyetujui penggunaan asiklovir oral sebagai terapi varisela pada anak sehat. Komite penyakit infeksi AAP menyatakan bahwa terapi asiklovir per oral yang diberikan dalam 24 jam penyakit pada anak sehat dengan varisela akan mengurangi lama demam satu hari dan sekitar 15\%-30\% lesi kulit serta manifestasi klinis (level of evidence: 5$)^{9}$. Artikel ini juga menyatakan bahwa komite penyakit infeksi AAP tidak merekomendasikan pemberian asiklovir per oral secara rutin pada anak sehat dengan varisela. Rekomendasi tersebut berdasarkan efek terapi, harga obat yang cukup tinggi dan ketersediaan obat dalam 24 jam pertama onset ruam serta belum diketahuinya kemungkinan resistensi VZV terhadap asiklovir.

Balfour HH dkk ${ }^{10}$ pada tahun 2001 melakukan suatu uji klinis acak ganda pada 177 pasien sehat yang terdiri dari anak-anak (2-11 tahun), remaja ( $\geq 12-18$ tahun) dan dewasa ( $\geq 19$ tahun) yang didiagnosis varisela. Pada penelitian ini pasien dibagi menjadi dua kelompok berdasarkan waktu onset ruam pada saat mengikuti penelitian, yaitu dalam 24 jam setelah onset ruam dengan $>24-48$ jam setelah onset ruam. Kedua kelompok diberi asiklovir per oral dosis antara $20 \mathrm{mg} /$ 
kg hingga maksimal 800 mg 4 kali per hari, diberikan selama 5-7 hari. Hasil penelitian ini menunjukkan bahwa pemberian dini asiklovir (dalam 24 jam setelah timbul lesi kulit) akan memperpendek lama sakit dan pemberian asiklovir cukup untuk lima hari karena tidak ditemukan manfaat lebih bila diberikan tujuh hari (level of evidence: $2 \mathrm{~b}$ ).

Telaah sistematik yang dilakukan oleh Klassen TP $\mathrm{dkk}^{11,12}$ pada tahun 2002 terhadap tiga uji klinis acak ganda $(\mathrm{n}=979)$ pada anak dan remaja sehat yang didiagnosis varisela dengan tujuan utama mencari bukti kemanjuran asiklovir dalam mengurangi gejala varisela (jumlah lesi, rasa gatal, demam) dan memperpendek lama sakit (level of evidence: 1A). Pada ketiga uji klinis acak ganda tersebut asiklovir diberikan dalam 24 jam setelah onset ruam selama 5-7 hari. Telaah sistematik menunjukkan bahwa asiklovir memiliki efek yang bermakna dalam menurunkan lama demam dari 1 hari (95\% IK-1,5,-05) sampai 1,3 hari (95\% IK-2,0,-0,6). Jumlah hari hingga tidak timbul lagi lesi baru, jumlah lesi maksimum, dan hilangnya rasa gatal menunjukkan hasil yang tidak konsisten. Telaah tersebut juga menunjukkan bahwa tidak terdapat perbedaan yang bermakna dalam hal komplikasi dan efek asiklovir yang tidak diinginkan antara asiklovir dan plasebo. Walaupun penelitian-penelitian diatas menunjukkan kemanjuran asiklovir, namun terapi asiklovir pada anak sehat dengan varisela masih merupakan kontroversi.

Memon IA $\mathrm{dkk}^{13}$ melakukan penelitian kohort pada 31 anak sehat dengan varisela umur 2-15 tahun yang diberi asiklovir per oral dalam 72 jam setelah onset ruam selama lima hari (level of evidence: $2 \mathrm{~b}$ ). Penelitian ini menyimpulkan bahwa asiklovir terbukti aman, tidak terdapat efek samping dan mengurangi timbulnya lesi baru dan lama sakit menjadi kurang dari lima hari setelah pengobatan dimulai. Namun, karena adanya pendapat tentang gangguan terbentuknya imunitas dan biaya, asiklovir sebaiknya hanya digunakan pada kelompok risiko tinggi seperti imunokompromais dan kasus yang berat. Gangguan terbentuknya imunitas tersebut mungkin disebabkan oleh viremia yang mendahului munculnya ruam chickenpox belum memberikan stimulasi antigen yang cukup sebelum terapi dengan asiklovir. ${ }^{4}$

\section{Pembahasan}

Suatu penelitian observasional di Italia menunjukkan bahwa 51\% dokter spesialis anak memberikan asiklovir pada 50\% kasus varisela tanpa penyulit (sekitar 25.000 anak). ${ }^{14}$ Hasil serupa didapatkan di poliklinik umum bagian IKA RSCM yaitu dari total 77 pasien varisela tanpa penyulit dalam lima tahun terakhir $65 \%$ diantaranya diberi terapi asiklovir per oral. Data tersebut menunjukkan bahwa walaupun AAP tidak merekomendasikan pemberian asiklovir pada anak sehat mayoritas dokter tetap meresepkan asiklovir. Pada presentasi kasus berbasis bukti ini penulis mencoba memaparkan rasionalisasi pemberian asiklovir pada anak sehat.

Virus varisela-zoster (VVZ) adalah salah satu dari 8 jenis herpes virus dari famili herpesviridae yang merupakan virus DNA alfa herpesvirus. Virus ini masuk tubuh terutama melalui kontak langsung dari lesi di kulit atau melalui droplet sekret saluran napas. Replikasi virus terjadi di kelenjar limfe lokal selama 2-4 hari diikuti dengan viremia primer yang terjadi 4-6 hari setelah inokulasi. Virus lalu bereplikasi di hepar, limpa, dan organ lain.Virus kembali dilepaskan ke dalam sirkulasi darah (viremia sekunder). Pada viremia sekunder terutama terjadi penyebaran partikelpartikel virus ke kulit, proses ini terjadi sekitar 14-16 hari setelah kontak. Setelah terjadi viremia sekunder, timbullah lesi vesikuler yang khas. ${ }^{1,3,15,16}$

Pada anak sehat, manifestasi klinis varisela umumnya ringan dan jarang menimbulkan komplikasi yang serius. Walaupun jarang, komplikasi dapat berupa infeksi bakteri kulit sekunder (1\%-4\% kasus), varisela pneumonia (jarang), ataxia serebelum (1dari 4000 kasus) dan meningoensefalitis (1 dari 40000 kasus). ${ }^{6,7,9}$ Infeksi kulit sekunder dan komplikasi neurologi lebih sering terjadi pada anak, sedangkan pneumonia lebih sering pada orang dewasa. ${ }^{7}$

Pengobatan pada anak sehat dengan varisela adalah simtomatik, antara lain dengan menggunakan lotion calamine untuk mengurangi gatal dan asetaminofen untuk demam dan rasa sakit. ${ }^{17}$ Pengobatan asiklovir untuk varisela pada pasien sehat berdasarkan kelompok umur, karena derajat keparahan varisela berbeda sesuai dengan umur. ${ }^{18}$ Dari hasil penelusuran, asiklovir terbukti aman serta dapat mengurangi lamanya demam dan jumlah lesi yang timbul. Dari segi biaya kesehatan, di Amerika Serikat kerugian ekonomi akibat varisela berhubungan dengan biaya perawatan di rumah sakit, biaya konsultasi dokter, biaya obat-obatan, dan terutama akibat hilangnya pemasukan orangtua yang menjaga anaknya di rumah atau di rumah sakit (lebih dari $90 \%$ dari total). ${ }^{19-21}$ Centers for Disease Control

Sari Pediatrī, Vol. 11, No. 6, April 2010 
and Prevention (CDC) merekomendasikan agar anakanak dengan varisela tetap tinggal di rumah selama enam hari setelah onset ruam. ${ }^{22}$ Untuk mencegah kerugian ekonomi, asiklovir dapat diberikan pada anak sehat karena hingga sekarang belum ditemukan efek samping yang membahayakan dan dikatakan mampu memperpendek lama sakit. ${ }^{6-8}$ Pada kasus ini, pasien menderita varisela tanpa penyulit, dan diberikan asiklovir dalam 48 jam setelah onset ruam. Setelah mendapatkan asiklovir selama dua hari pasien tidak demam dan jumlah lesi berkurang serta tidak terdapat efek samping dari asiklovir.

Neonatus memiliki risiko tinggi terjadinya visceral varicella. Bila ibu hamil menderita varisela pada minggu sebelum kelahiran, dianjurkan pemberian asiklovir pada bayi bila terdapat lesi waktu lahir, bila bayi tidak terdapat lesi, dapat diberikan Varicella Zoster Immune Globuline (V-ZIG) dan bayi dimonitor ketat. Bila varisela muncul dalam dua minggu pertama kehidupan, bayi diberikan asiklovir intravena selama lima hari. ${ }^{18}$

Pada pasien imunokompromais, varisela dapat menjadi berat bahkan menyebabkan kematian. Terjadinya penyulit dikarenakan respon imun yang gagal mengatasi replikasi dan penyebaran virus. Pemberian asiklovir intravena pada pasien imunokompromais adalah penting dan dianjurkan diberikan secepatnya, dalam 24 jam setelah timbulnya ruam walaupun jumlah lesi baru sedikit dan tampak sakit ringan. Hal ini karena pada pasien imunokompromais sulit untuk memprediksi derajat keparahan penyakit dan pengobatan yang lebih cepat memberikan hasil luaran yang lebih baik. ${ }^{23}$ Pasien imunokompromais termasuk leukemia, penyakit keganasan yang mendapatkan pengobatan kortikosteroid, dan status imunitas yang menurun. Pada kasus ini obat antivirus harus diberikan secepat mungkin dalam 24 jam setelah timbulnya ruam. ${ }^{1,2}$

Asiklovir merupakan obat sintetik jenis analog nukleosida purin, mempunyai sifat antiviral terhadap virus varisela-zoster dengan menghambat sintesis DNA virus. Untuk mengaktifkan asiklovir, obat ini harus diubah dahulu ke bentuk monofosfat oleh timidin kinase milik virus. Setelah terbentuk asiklovir-monofosfat (asiklo-GMP), oleh guanil kinase dan enzim milik sel hospes dirubah menjadi bentuk difosfat (asiklo-GDP) dan trifosfat (asiklo-GTP). Bentuk akhir ini menghentikan replikasi DNA virus melalui tiga cara yaitu, menghambat DNA-polimerase virus dengan berkompetisi terhadap desoksiguanosintrifosfat, inkorporasi ke dalam DNA virus yang sedang memanjang mengakibatkan terminasi biosintesis rantai DNA virus dan menonaktifkan DNA-polimerase virus. $^{3}$

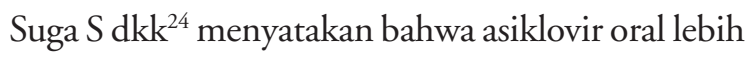
efektif dalam menghambat replikasi virus varisela-zoster pada viremia sekunder dibandingkan dengan viremia primer yang terjadi antara lima hari sebelum dan satu hari setelah onset klinis. ${ }^{16,25,26} \mathrm{Hal}$ tersebut mungkin disebabkan karena adanya perbedaan derajat induksi oleh timidin kinase milik virus pada saat viremia primer dan sekunder. Kallander CFR $\mathrm{dkk}^{27}$ mendukung pernyataan tersebut dengan membuktikan bahwa aktivitas timidin kinase milik virus mulai meningkat 3-5 hari sebelum onset klinis varisela.

Asiklovir dilaporkan mempunyai efek samping minimal karena obat ini hanya diserap oleh sel hospes yang terinfeksi oleh virus. Efek yang mungkin timbul pada terapi asiklovir per oral termasuk rasa mual, muntah, diare, dan nyeri kepala. ${ }^{4}$ Asiklovir dieksresi di ginjal dan dapat mengkristal pada tubulus ginjal pada pasien yang dehidrasi, karena itu pasien yang mendapatkan asiklovir sebaiknya mendapat hidrasi yang cukup. ${ }^{28}$ Obat antivirus asiklovir menjadi pilihan utama untuk pengobatan spesifik untuk infeksi VZV, namun obat ini tidak mencegah maupun mengobati VZV laten. Asiklovir tersedia dalam bentuk topikal, oral maupun intravena, namun hanya oral dan intravena yang berguna untuk melawan VZV. Pada pemberian peroral hanya sekitar 15\%-20\% asiklovir yang diserap. ${ }^{28}$

Pada anak sehat, AAP tidak merekomendasikan pemberian asiklovir secara rutin. American Academy of Pediatrics merekomendasikan pemberian asiklovir per oral pada kelompok dengan risiko tinggi terkena varisela berat atau penyulitnya seperti pasien sehat dan tidak hamil (usia di atas 13 tahun), anak-anak di atas 12 bulan dengan penyakit kulit kronis atau kelainan paru atau menerima terapi salisilat jangka panjang, pengobatan jangka pendek, intermiten atau inhalasi kortikosteroid. Sedangkan asiklovir intravena direkomendasikan pada anak-anak imunokompromais (termasuk yang menerima terapi kortikosteroid dosis tinggi) dan kasus varisela dengan penyulit. ${ }^{4,9}$ Pada pasien imunokompromais, asiklovir terbukti menurunkan morbiditas dan mortalitas bila diberikan dalam 24 jam pertama setelah onset ruam. ${ }^{29}$ Dosis asiklovir per oral adalah $20 \mathrm{mg} / \mathrm{kg}$ per kali (dosis maksimum 800 
mg) empat kali sehari selama lima hari dan dimulai dalam 24 jam setelah onset ruam, ${ }^{9}$ sedangkan asiklovir intravena pada umumnya diberikan dengan dosis 500 $\mathrm{mg} / \mathrm{m}^{2}$ setiap 8 jam selama 7-10 hari. ${ }^{9,29}$

Pertimbangan untuk tidak memberikan terapi asiklovir pada anak sehat adalah bahwa varisela pada anak sehat dapat sembuh sendiri. Gejala penyakit ringan walaupun tidak diberikan asiklovir, kurangnya bukti bahwa asiklovir dapat mencegah komplikasi yang terjadi, dan kemungkinan terjadinya resistensi asiklovir pada penggunaan yang rutin dan luas. Terapi asiklovir diduga dapat menganggu respon imun terhadap VZV dan menyebabkan terjadinya chickenpox berulang. ${ }^{4}$ Terdapat teori bahwa penggunaan asiklovir dapat mempengaruhi respon imun sehingga mengubah perjalanan alami varisela dan mengakibatkan terjadinya reaktivasi herpes zoster lebih dini. Namun, uji klinis oleh Englund JA dkk ${ }^{30}$ pada tahun 1990 menyimpulkan bahwa pemberian asiklovir oral selama 5-7 hari sebagai terapi varisela pada anak sehat tidak mempengaruhi respons antibodi terhadap dua protein dari VZV, gp1 dan IE62 (p170) pada 28 hari dan 1 tahun setelah kejadian varisela. Hal ini didukung oleh uji klinis Balfour $\mathrm{dkk}^{8}$ yang menyatakan titer antibodi terhadap VZV pada kelompok asiklovir dan plasebo pada 28 hari setelah varisela adalah sama. Englund JA dkk ${ }^{30}$ dan Balfour $\mathrm{HH} \mathrm{dkk}^{6,8}$ membuktikan bahwa terapi asiklovir tidak mempengaruhi respon imun humoral.

\section{Kesimpulan}

Asiklovir hanya diberikan secara rutin pada pasien imunokompromais dan tidak dianjurkan diberikan secara rutin pada untuk varisela tanpa penyulit pada anak sehat. Walaupun terdapat beberapa bukti yang menyatakan bahwa asiklovir mampu mengurangi lamanya demam dan jumlah maksimum lesi bila diberikan dalam 24 jam pertama setelah timbulnya ruam serta mengurangi kerugian ekonomi. Hal ini dengan pertimbangan bahwa pada varisela pada anak sehat dapat sembuh sendiri dan biasanya ringan, asiklovir tidak mengurangi terjadinya komplikasi varisela, harga asiklovir yang mahal, dan belum diketahui secara pasti kemungkinan terjadinya resistensi VZV terhadap asiklovir. Pemberian asiklovir pada anak dengan varisela tanpa penyulit perlu pertimbangan yang matang.

\section{Daftar Pustaka}

1. Myers MG, Seward JF, LaRussa PS. Varicella-zoster virus. Dalam: Kliegman RM, Behrman RE, Jenson HB, Stanton BF, penyunting. Nelson Textbook of Pediatrics. Edisi ke-18. Philadelphia: Saunders Elsevier;2007. h 1366-72.

2. UKK Infeksi dan Penyakit Tropis. Varisela. Dalam: Soedarmo SSP, Garna H, Hadinegoro SRS, Satari HI. Buku Ajar Infeksi \& Pediatri Tropis. Edisi ke-2. Jakarta: Badan Penerbit IDAI; 2002. h. 134-42.

3. Heininger U, Seward JF. Varicella. Lancet 2006;368:136576.

4. Kennedy N, McKendrick MW. Controversies in varicella: vaccine and acyclovir. Current Opinion in Infectious Diseases 1996;9:203-9.

5. Oxford Centre of Evidence-based Medicine. Oxford Centre for evidence-based medicine levels of evidence (March 2009). Diunduh dari http://www.cebm.net/index. aspx?o=1025. Diakses tanggal 17 Mei 2010.

6. Balfour HH, Kelly JM, Suarez CS, Heussner RC, Englund JA, Crane DD, dkk. Acyclovir treatment of varicella in otherwise healthy children. J Pediatr 1990;116:633-9.

7. Dunkle LM, Arvin AM, Whitley RJ, Rotbart HA, Feder HM Jr, Feldman S, dkk. A controlled trial of acyclovir for chickenpox in normal children. N Engl J Med 1991;325:1539-44.

8. Balfour HH, Rotbart HA, Feldman S, Dunkle LM, Feder HM Jr, Prober CG, dkk. Acyclovir treatment of varicella in otherwise healthy adolescents. J Pediatr 1992;120(p1):664-5.

9. Committee on Infectious Diseases. The use of oral acyclovir in otherwise healthy children with varicella. Pediatrics 1993;91:674-76.

10. Balfour HH, Edelman CK, Anderson RS, Reen NV, Slivken RM, Marmor LH, dkk. Controlled trial of acyclovir for chickenpox evaluating time of initiation and duration of therapy and viral resistance. Pediatr Infect Dis J 2001;20:919-26.

11. Klassen TP, Belseck EM, Wiebe N, Hartling L. Acyclovir for treating varicella in otherwise healthy children and adolescents: a systematic review of randomised controlled trials. BMC Pediatrics 2002;2:1-9.

12. Klassen TP, Hartling L. Acyclovir for treating varicella in otherwise healthy children and adolescents (review). Cochrane Database of Systematic Reviews 2005;4.

13. Memon IA, Jamal A, Memon H. An experience of oral acyclovir in treating children with varicella infection. Pak 
J Med Sci 2008;24:590-4.

14. Volpi A, Gentile G, Pica F, Suligoi B. Antiviral treatment of varicella in pediatric practice in the latium region of italy: results of an observational study. Pediatr Infect Dis J 2002;21:739-42.

15. Ziebold C, von Kries R, Lang R, Weigl J, Schmitt HJ. Severe complications of varicella in previously healthy children in germany: a 1-year survey. Pediatrics 2001;108:e79.

16. Grose C. Variation on a theme by fenner: the pathogenesis of chickenpox. Pediatrics 1981;68:735-7.

17. Hudgings L, Kelsberg G, Safranek S, Neher JO. Do antipyretics prolong febrile illness? J Fam Pract 2004;53:57-8,61.

18. Balfour HH. Current management of varicella zoster virus infections. J Med Vir 1993;1:74-81.

19. McKendrick MW. Controversies in management: acyclovir for childhood chickenpox. BMJ 1995;310:108-9.

20. Brunell PA. Chickenpox-examining our options. N Engl J Med 1991;325:1577-99.

21. Preblud SR. Complications and costs. Pediatrics 1985;78:728-35.

22. Centers for Diseases Control and Prevention. Infectious diseases information: varicella-zoster virus. CDC: National Center for Infectious Diseases 2010. Diunduh dari http://www.cdc.gov/ncidod/diseases/list_varicl.htm. Diakses pada tanggal 20 Mei 2010.

23. Kesson AM, Grimwood K, Burgess MA, Ferson MJ, Gilbert GL, Hogg G, dkk. Acyclovir for the prevention and treatment of varicella zoster in children, adolescents and pregnancy. J Pediatr Child Health 1996;21:211-7.

24. Suga S, Yoshikawa T, Ozaki T, Asano Y. Effect of oral acyclovir against primary and secondary viraemia in incubation period of varicella. Arch Dis Child 1993;69:639-43.

25. Ozaki T, Ichikawa T, Matsui Y, Nagai T, Asano Y, Yamanishi $\mathrm{K}$, dkk. Viremic phase in non-immunocompromised children with varicella. J Pediatr 1984;104:85-7.

26. Asano Y, Itakura N, Hiroishi Y, Hirose S, Nagai T, Ozaki T, dkk. Viremia is present in incubation period in nonimmunocompromised children with varicella. J Pediatr 1985;106:69-71.

27. Kallander CFR, Gronowitz JS, Olding-Stenkvist E. Varicella zoster virus deoxythymidine kinase is present in serum before the onset of varicella. Scand J Infect Dis 1989;21:255-7.

28. Gershon AA, LaRussa P. Varicella-zoster virus infections. Dalam: Ghershon AA, Hotez PJ, Katz SL, penyunting. Krugman's Infectious Diseases of Children. Edisi ke-11. Philadelphia: Mosby;2004. h 785-816.

29. Prober CG, Kirk LE, Keeney RE. Acyclovir therapy of chickenpox in immunocompromised children-a collaborative study. J Pediatr 1992;101:622-5.

30. Englund JA, Arvin AM, Balfour HH. Acyclovir treatment for varicella does not lower gpI and IE-62 (p170) antibody responses to varicella-zoster virus in normal children. J Clin Microbiol 1990;28:2327-30. 


\section{Lampiran}

Tabel. Rangkuman penelitian terapi asiklovir pada varisela tanpa penyulit

\begin{tabular}{|c|c|c|c|c|}
\hline Penulis & Pasien & $\begin{array}{c}\text { Jenis } \\
\text { penelitian }\end{array}$ & Intervensi & Luaran \\
\hline $\begin{array}{l}\text { Balfour dkk } \\
(1990)\end{array}$ & $\begin{array}{c}102 \\
(5-16 \text { thn })\end{array}$ & $\begin{array}{l}\text { Uji klinis } \\
\text { acak ganda } \\
\text { (level of } \\
\text { evidence: } 1 \mathrm{~b} \text { ) }\end{array}$ & $\begin{array}{l}\text { Asiklovir } \\
5-7 \text { thn }: 20 \mathrm{mg} / \mathrm{kg} \\
7-12 \mathrm{thn}: 15 \mathrm{mg} / \mathrm{kg} \\
12-16 \text { thn: } 10 \mathrm{mg} / \mathrm{kg} \\
\text { diberikan } 4 \mathrm{x} / \mathrm{hari} \text { selama } 5-7 \text { hari } \\
\text { Plasebo }\end{array}$ & $\begin{array}{l}\text { Lama demam, lama hari hingga ti- } \\
\text { dak timbul lesi baru, jumlah lesi } \\
\text { maksimum, berkurangnya jumlah lesi } \\
\text { dan rasa gatal }\end{array}$ \\
\hline $\begin{array}{l}\text { Dunkle dkk } \\
\text { (1991) }\end{array}$ & $\begin{array}{c}815 \\
(2-12 \text { thn })\end{array}$ & $\begin{array}{l}\text { Uji klinis } \\
\text { acak ganda } \\
\text { (level of } \\
\text { evidence: } 1 \mathrm{~b} \text { ) }\end{array}$ & $\begin{array}{l}\text { Asiklovir } \\
20 \mathrm{mg} / \mathrm{kg} / \mathrm{kali}, 4 \mathrm{kali} / \mathrm{hari}, \\
\text { selama } 5 \text { hari } \\
\text { Plasebo }\end{array}$ & $\begin{array}{l}\text { Jumlah lesi maksimum, jumlah pasien } \\
\text { dengan lesi }>500\end{array}$ \\
\hline $\begin{array}{l}\text { Balfour dkk } \\
(1992)\end{array}$ & $\begin{array}{c}62 \\
(13-18 \text { thn })\end{array}$ & $\begin{array}{l}\text { Uji klinis } \\
\text { acak ganda } \\
\text { (level of } \\
\text { evidence: } 1 \mathrm{~b} \text { ) }\end{array}$ & $\begin{array}{l}\text { Asiklovir } \\
800 \mathrm{mg} / \mathrm{kali}, 4 \text { kali /hari, } \\
\text { selama } 5 \text { hari } \\
\text { Plasebo }\end{array}$ & $\begin{array}{l}\text { Jumlah hari hingga jumlah lesi mak- } \\
\text { simum tercapai dan rasa gatal ber- } \\
\text { kurang, jumlah lesi maksimum }\end{array}$ \\
\hline $\begin{array}{l}\text { Balfour dkk } \\
(2001)\end{array}$ & $\begin{array}{c}177 \\
(2-48 \text { thn })\end{array}$ & $\begin{array}{l}\text { Uji klinis } \\
\text { acak ganda } \\
\text { (level of } \\
\text { evidence: } 2 \mathrm{~b} \text { ) }\end{array}$ & $\begin{array}{l}\text { Asiklovir } \\
20 \mathrm{mg} / \mathrm{kg} / \mathrm{kali}(\mathrm{max} .800 \mathrm{mg}) \\
4 \mathrm{kali} / \mathrm{hari} \text { selama } 5 \text { atau } 7 \text { hari }\end{array}$ & $\begin{array}{l}\text { Efek waktu dimulainya terapi asiklovir } \\
\text { terhadap viral sheeding }\end{array}$ \\
\hline $\begin{array}{l}\text { Memon dkk } \\
\quad(2008)\end{array}$ & $\begin{array}{c}31 \\
(2-15 \text { thn })\end{array}$ & $\begin{array}{l}\text { Kohort } \\
\text { (level of } \\
\text { evidence: } 2 \mathrm{~b} \text { ) }\end{array}$ & $\begin{array}{l}\text { Asiklovir : } 80 \mathrm{mg} / \mathrm{kg} / \text { hari, selama } \\
5 \text { hari }\end{array}$ & $\begin{array}{l}\text { Lama sakit, derajat keparahan ruam } \\
\text { dan rasa gatal, komplikasi varisela }\end{array}$ \\
\hline
\end{tabular}

